світ людських цінностей. Спілкування з музичним мистецтвом у вищому навчальному закладі стає шляхом становлення особистісного світосприйняття.

Предмет «Диригування» $\epsilon$ одним із важливих у системі професійної підготовки майбутніх учителів музики. Випускник вищого навчального закладу повинен бути різнобічно розвиненим музикантом, який володіє знаннями та навичками, необхідними для подальшої практичної діяльності у якості керівника хорового колективу, що потребує виховання у студентів практичних навичок диригування, вимагає не тільки роботи під керівництвом викладача, але й самостійної роботи студента.

В умовах відродження хорової культури, яка в історії національної культури $\epsilon$ визначальною традицією, питання диригентської педагогіки набувають особливого змісту. Диригентська діяльність учителя музики є складною системою, що зумовлює необхідність вивчення цілого комплексу диригентсько-хорових дисциплін. Його основу складають диригування, хоровий клас, хорознавство та хорова практика у школі.

Самостійна робота студента сприяє поглибленню і розширенню знань, формуванню інтересу до пізнавальної діяльності, оволодінню прийомами процесу пізнання, розвитку пізнавальних здібностей. Тому, на нашу думку, вона є головним чинником підвищення ефективності підготовки майбутнього вчителя музики.

\title{
Література
}

1. Доронюк В. Методика викладання диригування / В. Доронюк. - Івано-Франківськ, 2005. С. 32-42. 2. Ержемский Г. Л. Психология дирижирования: Некоторые вопросы исполнительства и творческого взаимодействия дирижера с музыкальным коллективом / Г. Л. Ержемский. - М. : Музыка, 1988. - 280 с. 3. Музичний енциклопедичний словник /[гол.ред. Г.В.Келдиш]. - М. : Радянська енциклопедія, 1990. - 672 с. 4. Юцевич Ю. Є. Музика. Словник-довідник / Юрій Євгенович Юцевич. - Тернопіль : «Навчальна книга - Богдан», 2003. - 275 с.

УДК 378. 011. 3 - $051:[001.89+378.147]$

В. В. Прошкін, кандидат пед. наук, доиент, Луганський наџіональний університет імені Тараса Шевченка

\section{ІНТЕГРАЦІЯ НАУКОВО-ДОСЛІДНОЇ І НАВЧАЛЬНОЇ РОБОТИ В УНІВЕРСИТЕТСЬКІЙ ПІДГОТОВЦІ МАЙБУТНІХ УЧИТЕЛІВ ЯК СУЧАСНА ПЕДАГОГІЧНА ПРОБЛЕМА}

Прошкін В. В. Інтеграція науково-дослідної і навчальної роботи в університетській підготовці майбутніх учителів як сучасна педагогічна проблема.

У статті наголошено на необхідності розроблення спеціальної педагогічної системи інтеграції університетської науки й освіти, що визначає стратегічний напрямок наукового розвитку університету й розкриває технологію покращення професійної підготовки майбутніх учителів. Установлено, що в сучасних дослідженнях недостатньо вирішено проблему максимального поєднання науки 3 навчальним процесом на всіх його етапах.

Ключові слова: інтеграція науково-дослідної й навчальної роботи, університетська підготовка, майбутній учитель.

Прошкин В. В. Интеграция научно-исследовательской и учебной работы в университетской подготовке будущих учителей как современная педагогическая проблема.

В статье отмечена необходимость разработки специальной педагогической системы интеграции университетской науки и образования, которая определяет стратегическое направление научного развития университета и раскрывает технологию улучшения профессиональной подготовки будущих учителей. Установлено, что в современных исследованиях недостаточно разрешена проблема максимального сочетания науки с учебным процессом на всех его этапах.

Ключевые слова: интеграция научно-исследовательской и учебной работы, университетская подготовка, будущий учитель. 
Proshkin V. V. An integration of scientific and research and educational work in the process of future teachers' university training as modern pedagogical problem.

This article is about need to work out some special pedagogical system of university integration of science and education that defines strategic direction of science development of the university and discloses a technology of improvement future teachers' professional training. The author analyzed the most significant literary sources and established that modern researches insufficiently solve problem of maximum association of science and educational process at all stages.

Key words: integration of scientific and research and educational work, university training, future teachers.

Питання вдосконалення університетської підготовки майбутніх учителів не втрачає своєї актуальності і значущості. Сучасна середня школа вимагає від випускників ВНЗ не тільки високого рівня знань, а й уміння проводити власні педагогічні дослідження 3 подальшим упровадженням результатів наукових пошуків у практику.

Підвищення якості професійної підготовки майбутніх педагогів ми бачимо в максимальній інтеграції науково-дослідної й навчальної роботи в університеті. Водночас реальна практика професійної підготовки майбутніх учителів свідчить про недостатню кількість реально діючих механізмів такого об'єднання. Крім того, підвищення ролі університету як вагомого наукового центру вимагає нових підходів до організації наукової роботи й підготовки педагогічних кадрів. Виникає необхідність у розроблення спеціальної педагогічної системи інтеграції університетської науки й освіти, що визначає стратегічний напрямок наукового розвитку ВНЗ, розкриває технологію удосконалення професійної підготовки вчителів, а також виступає орієнтиром перспективного планування наукової діяльності.

Meта cmammi - у межах теми «Інтеграція науково-дослідної й навчальної роботи в університетській підготовці майбутніх учителів» (державний реєстраційний номер 0108U07930), що розробляється в Луганському національному університеті імені Тараса Шевченка, вважаємо за необхідне розглянути основні фундаментальні роботи науковців, які вивчали вищезазначену проблему.

На наш погляд, доробки сучасних науковців стануть підгрунтям у розробці педагогічної системи інтеграції науково-дослідної й навчальної роботи в університетській підготовці майбутніх учителів.

Аналіз наукової літератури показав, що інтеграційні процеси науки й освіти почали реалізовуватися в Україні переважно з 80-90 pp. 20 століття. Тому доцільно розглянути наукові роботи саме сучасних учених.

Педагогічна практика дозволяє стверджувати - останнім часом поступово зростає інтерес до питання реалізації навчального процесу через наукову діяльність, що сприяло появі низки дисертаційних досліджень. Яскравим прикладом вивчення інтеграції науки, освіти й виробництва в педагогіці вищої школи стали сучасні дисертаційні дослідження російських науковців: докторські дисертації (3. Сазонова, О. Глущенко, А. Козлов, В. Чернолес) i кандидатські дисертації (П. Васильєв, О. Загора, Є. Неборський, Ю. Шагіна).

Найбільш значущими для нашої роботи ідеї, висунуті О. Глущенко [1], який вивчав вплив інтеграції навчальної й наукової діяльності викладача вищої школи на якість підготовки фахівців. Така інтеграція розглядається автором як цілісне утворення, що відображає в єдності соціально-професійні ролі викладача й забезпечує педагогічну взаємодію зі студентами, їхнє особистісне зростання й високу якість підготовки.

Варто зазначити, що інтеграцію навчальної й наукової діяльності викладача вищої школи автор змістовно розкриває через поняття «стиль наукового мислення й діяльності», під яким розуміє стійку єдність способів і засобів діяльності, що забезпечують эї творчий характер і цілісність.

До педагогічних умов, що забезпечують вплив інтеграції навчальної й наукової діяльності на підвищення якості підготовки фахівця, О.Глущенко відносить такі: 
збагачення наукового змісту навчальних занять; ознайомлення студентів 3 лабораторією наукової творчості й залучення до науково-дослідної діяльності; орієнтація на розвиток сучасного стилю наукового мислення; проблематизація змісту освіти, що передбачає побудову цілісної системи навчально-пізнавальних завдань; інформаційне забезпечення інтеграції навчальної й наукової діяльності викладача вищої школи.

У дослідженні 3. Сазонової на тему «Інтеграція освіти, науки й виробництва як методологічна підстава підготовки сучасного інженера» [2] наголошується, що підготовка сучасного інженера на основі системної інтеграції освіти, науки й виробництва - не тільки наукова проблема, але й напрям державної політики.

Дисертантом установлено, що інтеграція $є$ методологічною підставою підготовки конкурентоздатного фахівця під час виконання таких умов: 1) формування єдиного освітнього простору технічного ВНЗ, науки й виробництва; 2) управління розвитком інтеграційних процесів у технічному ВНЗ за допомогою продуктивної взаємодії всіх зацікавлених структур; 3) вбудованність інтеграції освіти, науки й виробництва в зміст підготовки майбутніх інженерів; 4) проектування моделі інтеграції освіти, науки й виробництва на основі загальних і педагогічних принципів з урахуванням мети, завдань, чинників технічної освіти, змісту підготовки майбутніх інженерів.

Слід констатувати відсутність дисертаційних досліджень з інтеграції науково-дослідної й навчальної роботи, що націлені на підготовку майбутнього вчителя. Водночас реалізовано низку досліджень (3. Сазонова, А. Козлов, Ю. Шагіна), у яких розглядається підготовка фахівців технічних наук. Уважаємо, що концептуальні підходи, запропоновані в цих роботах, за певної модернізації можуть бути застосовані під час розроблення нашої системи інтеграції науково-дослідної й навчальної роботи.

Зазначимо також, що в усіх вищеназваних дисертаціях акцент зроблено не стільки на реалізації процесу університетської підготовки майбутніх фахівців через дослідницьку діяльність, а скоріше на організацію різних форм так званого «соціального партнерства між наукою, освітою й виробництвом» (за З. Сазоновою) [2].

Цікавою нам уважається монографія С. Якушевої «Університетський освітній округ інтеграція науки, освіти й практики» [3], що розкриває історію формування університетських округів і їх значення для інноваційної діяльності в освіті, а також монографія Б. Супяна «Дослідницькі університети США: механізм інтеграції науки й освіти» [4], у якій здійснено аналіз структури й тенденцій розвитку науки й освіти США, механізмів інтеграції та організації науки й освіти, ролі держави в розвитку університетів і проведенні наукових досліджень.

Водночас аналіз усіх наукових робіт дозволяє говорити про відсутність загальної ідеї, яку було б покладено в основу інтеграції науки й освіти. Більшість педагогічних технологій 3 реалізації інтеграції $\epsilon$ результатом практичної потреби розв'язання конкретних педагогічних завдань i не можуть розглядатися в контексті цілісної університетської підготовки майбутніх учителів.

Здійснений нами аналіз каталогів національної бібліотеки України імені В. I. Вернадського (режим доступу: http://www.nbuv.gov.ua), а також протоколів засідань Міжвідомчої ради з координації наукових досліджень НАПН України (режим доступу: http://naps.gov.ua) дозволяє стверджувати, що в Україні донині не проводилися масштабні дослідження, спрямовані на вивчення інтеграційних процесів науки й освіти, зокрема в контексті підготовки майбутніх учителів. Натомість реалізовано низку досліджень, присвячених проблемам організації науково-дослідної діяльності в процесі навчання, а також формуванню дослідницьких компетенцій у студентів університетів.

У результаті наукового пошуку встановлено, що найбільш розробленими $є$ історикопедагогічні розвідки з різних аспектів організації й реалізації наукової роботи в системі вищої школи (О. Микитюк, Н. Пузирьова, О. Мартиненко, В. Кузнецова, О. Гнізділова, Г. Кловак, О. Адаменко та ін.).

Авторами на основі системного аналізу теорії й практики організації науково-дослідної 
роботи у ВНЗ України відтворено ії генезис у 19-20 ст.: визначено й науково обгрунтовано етапи, тенденції, особливості розвитку науки у ВНЗ; передумови іiі організації й становлення; особливості системи підготовки педагогічних кадрів; погляди вітчизняних педагогів на роль і значення студентської науки в українських університетах; положення про сутність різних освітніх реформ і їх взаємозв'язок зі змістом науково-дослідної роботи студентів тощо.

Уважаємо фундаментальним для нашої роботи докторське дослідження О. Микитюка [5], у якому розглядається становлення й розвиток організації науково-дослідної роботи у ВНЗ України в 19 ст. Автором на основі системного аналізу теорії й практики організації науково-дослідної роботи у ВНЗ України відтворено іï генезу в 19 ст., визначено й науково обгрунтовано етапи, тенденції, особливості їі розвитку, виявлено передумови організації науково-дослідної роботи у ВНЗ, особливості й ступінь ефективності системи підготовки й виховання наукових кадрів в університетах України.

У докторському дослідженні О. Гнізділової [6] розглянуто діяльність науковопедагогічних шкіл вищих педагогічних навчальних закладів Східної України 20 століття. Автором 3'ясовано сутність наукової школи як ефективної та перспективної форми науково-дослідної діяльності ВНЗ України й підготовки науково-педагогічних кадрів.

Цікавими ми вважаємо основні ознаки науково-педагогічної школи, що були виокремлені автором: наявність наукового лідера 3 високим рівнем педагогічної майстерності; оригінальність наукових пошуків та визначений характерний стиль роботи наукового колективу; ініціювання прогресивної або інноваційної наукової ідеї та продуктивної дослідницької програми; єдність тематики наукового пошуку керівника та учнів; традиція наступності й передавання світосприймання, норм, цінностей наукової спільноти, технологій науково-дослідної роботи; наукова значущість розробок наукової школи; наявність системи підготовки науково-педагогічних кадрів, органічних форм спілкування й взаємного впливу членів співтовариства.

Наступний напрям сучасних наукових пошуків спрямований на розв'язання проблем формування знань, умінь і навичок науково-дослідної роботи у студентів. До цього напряму ми відносимо ряд дисертаційних досліджень (Н. Уйсімбаєва, С. Щербина, Н. Гловин, І. Сенча, А. Нєлепова, Г. Самбаманія, С. Спіцин та ін.).

Найбільший інтерес представляють дослідження, спрямовані на формування вищеназваних компетенцій у майбутніх учителів (М. Князян, С. Кулик, Л. Султанова, М. Фалько, П. Горкуненко, О. Миргородська, О. Рогозіна, В. Лісовий, І. Луценко, В. Кулешова, Т. Мишковська, О. Сгорова, Л. Бурчак та ін.).

Авторами розкрито сутність, структуру і функції дослідницької діяльності студентів; виявлено закономірності організації дослідницької діяльності у вітчизняному й зарубіжному досвіді; виокремлено етапи (мотиваційний, когнітивний, процесуальний, рефлексивний) формування пошуково-дослідницьких умінь у студентів.

Так, у межах докторського дослідження М. Князян [7] висвітлено проблему формування самостійно-дослідницької діяльності майбутніх учителів іноземних мов. Автором розкрито сутність, структуру та функції самостійно-дослідницької діяльності студентів; виявлено закономірності організації самостійно-дослідницької діяльності у вітчизняному й зарубіжному досвіді; побудовано компетентнісну модель учителя іноземних мов та визначено функціональну роль самостійно-дослідницької діяльності.

Цікавими для нашого дослідження $є$ розроблена педагогічна система формування самостійно-дослідницької діяльності студентів, закономірності їі функціонування на всіх етапах ступеневої освіти (бакалавр - спеціаліст - магістр), а також технологія діагностики якості формування самостійно-дослідницької діяльності майбутніх учителів.

У дисертації І. Луценко [8], що виконувалася в ЛНУ імені Тараса Шевченка, теоретично обгрунтовано й експериментально перевірено систему формування дослідницької культури майбутніх учителів у діяльності студентських наукових товариств, що побудована з урахуванням сутнісних характеристик, функцій дослідницької 
культури майбутнього вчителя та особливостей студентських наукових товариств. Система охоплює цільовий, змістовний, операційно-діяльнісний, результативний компоненти, передбачає організаційно-методичне забезпечення поетапного розвитку всіх компонентів дослідницької культури майбутніх учителів у діяльності студентського наукового товариства.

Сучасний фонд наукових знань 3 інтеграції науки й освіти представлений дослідженнями авторів, що вийшли друком у провідних фахових виданнях (В. Іщенко, Г. Іванов, І. Дьожина, М. Іванчук, В. Шорін, Г. Балихін, В. Шудегов, О. Левчишена, С. Шушкевич, В. Онопрієнко, В. Шибаєв, О. Кубасов, О. Семенюк, С. Тульчинська, В. Курейчик, Л. Гохберг, Ю. Тягунова, М. Берулава та ін.), у тому числі при підготовці майбутніх учителів (В. Левченко, О. Бабенко, О. Іванченко, В. Петров, М. Овчинникова та ін.).

Установлено, що найбільш вивченими $є$ різні аспекти науково-дослідної, творчопошукової роботи в середній школі (С. Васильєва, Н. Недодайко, Л. Левченко, А. Сологуб, Л. Тихенко, Г. Пустовіт, О. Марченко та ін.). Особливий інтерес становить наукове обгрунтування й експериментальна перевірка етапів організації науководослідної діяльності старшокласників, а також роль педагогічної практики для формування дослідницьких компетенцій у майбутніх учителів.

Уважаємо важливим зробити аналіз цих робіт, оскільки він допоможе визначити, які саме якості необхідні сучасному випускнику університету, щоб бути успішним організатором науки у школі, уміло розвивати навички дослідницької діяльності у свої вихованців. Окрім того, необхідно вміти використовувати значний потенціал, що має педагогічна практика для професійного становлення вчителя-дослідника.

Важливим у контексті наших наукових пошуків $\epsilon$ дисертаційне дослідження Л. Тихенко, в якому обгрунтована й експериментально перевірена сучасна навчальновиховна система «Малая академия наук Украины» [9]. Автором апробовано організаційно-педагогічні умови й методику формування творчих здібностей старшокласників у процесі дослідницької діяльності, структуровано зміст, визначено й схарактеризовано етапи, рівні і критерії ефективності навчально-виховної діяльності МАН для формування творчих здібностей старшокласників.

Здійснений комплексний аналіз наукової літератури дозволяє констатувати, що нині поступово почали виконуватися дослідження, в яких розкривається сутність, а також деякі особливості інтеграції науки й освіти. У розвідках сучасних авторів розглядаються різні аспекти професійної підготовки фахівців через таку інтеграцію. Більшість науковців, які займаються даною проблемою, відзначають необхідність інтеграції науки й освіти для сучасної вищої школи. Водночас недостатньо розробленими залишаються теоретичні й методичні основи інтеграції в контексті підготовки сучасного вчителя, що дозволяє виокремити суперечності: між прагненням України до входження в європейський науково-освітній простір і недостатнім рівнем науково-дослідної діяльності у ВНЗ, слабким зв'язком науки 3 навчальним процесом, недосконалістю форм i методів організації наукових досліджень у процесі професійної підготовки майбутніх учителів; між широкими можливостями вищих навчальних закладів до організації й проведення наукових досліджень, виховання вчителя-дослідника та віддаленістю науково-дослідної роботи від навчального процесу; між потребою дослідницької функції у професійній діяльності педагога й недостатньою розробленістю теоретичного й методичного забезпечення інтеграції наукової і навчальної роботи в підготовці студентів; між підвищеними вимогами до професійної підготовки майбутніх учителів, які повинні володіти високим рівнем дослідницької культури, науковим потенціалом, що реалізується в педагогічній творчості під час вирішення складних практичних задач і відсутністю в більшості ВНЗ системної науково-дослідної роботи викладачів і студентів, що виступає однією з основних умов створення науко-орієнтованого освітнього середовища. 
Отже, аналіз наукової літератури дозволяє нам говорити, що в Україні практично не проводилися дослідження, присвячені проблемі зближення двох найважливіших сфер сучасного суспільства - освіті й науки, особливо в контексті підготовки майбутніх учителів. Крім того, недостатньо робіт, в яких розкриваються питання організації наукової діяльності в університеті, при якій відбувається максимальне впровадження наукової діяльності в навчальний процес на всіх його етапах. Спільний науковий й навчальний потенціал вищої школи недостатньо використовується для підготовки майбутніх учителів. Механізмів інтеграції науково-дослідної й навчальної роботи, що реально діють у сучасних умовах, поки що не створено.

Перспективу подальшої наукової роботи ми бачимо в обгрунтуванні й розробленні педагогічної системи інтеграції науково-дослідної й навчальної роботи в університетській підготовці майбутніх учителів.

1. Глущенко А. А. Влияние интеграции учебной и научной деятельности преподавателей высшей школы на качество подготовки специалиста : дисс. ... доктора пед. наук : 13.00.01 / Глущенко Александр Алексеевич. - М., 1998. - 431 с. 2. Сазонова 3. С. Интеграция образования, науки и производства как методологическое обоснование подготовки современного инженера : дисс. ... доктора пед. наук : 13.00.01 / Сазонова Зоя Сергеевна. - Казань, 2008. - 439 с. 3. Якушева С. Д. Университетский образовательный округ - интеграция науки, образования и практики : [монография] / С. Д. Якушева. - М. : АПКиППРО, 2009. - 200 с. 4. Супян В. Б. Исследовательские университеты США: механизм интеграции науки и образования : монография / В. Б. Супян. - М. : Магистр, 2009. - 339 с. 5. Микитюк О. М. Теорія і практика організації науково-дослідної роботи у вищих закладах освіти України в XIX ст. : дис. ... д-ра пед. наук : 13.00.01 / Микитюк Олександр Миколайович. - Х., 2003. - 405 с. б. Гнізділова О. А. Становлення i розвиток наукових шкіл у вищих педагогічних навчальних закладах Східної України в XX столітті : дис. ... д-ра пед. наук : 13.00 .01 / Гнізділова Олена Анатоліївна. - Х., 2012. - 499 с. 7. Князян М. О. Система формування самостійно-дослідницької діяльності майбутніх учителів іноземних мов у процесі ступеневої підготовки : автореф. дис. на здобуття наук. ступеня доктора пед. наук : спец. 13.00.04 «Теорія і методика професійної освіти» / М. О. Князян. - Одеса, 2007. 45 с. 8. Луценко І. В. Формування дослідницької культури майбутніх учителів у діяльності студентського наукового товариства : дис. ... канд. пед. наук : 13.00 .04 / Луценко Ірина Володимирівна. - Луганськ, 2011. - 212 с. 9. Тихенко Л. В. Формування творчих здібностей старшокласників у процесі дослідницької діяльності в Малій академії наук України. : дис. ... канд. наук : 13.00.07 / Тихенко Лариса Володимирівна. - Полтава, 2009. - 199 с.

УДК 372.878

Л. М. Ракімянська, кандидат пед. наук, доиент, Криворізький педагогічний інститут ДВНЗ «Криворізький начіональний університет»

\section{НАУКОВО-ПЕДАГОГІЧНА ДУМКА ПРО МОРАЛЬНО-ЕСТЕТИЧНЕ ВИХОВАННЯ ЗАСОБАМИ МУЗИЧНОГО МИСТЕЦТВА}

Ракітянська Л. М. Науково-педагогічна думка про морально-естетичне виховання засобами музичного мистецтва.

У статті проаналізовано погляди сучасних науковців на проблему взаємозв'язку морального та естетичного у філософських та психолого-педагогічних дослідженнях.

Ключові слова: моральне, естетичне, морально-естетичне виховання.

Ракитянская Л. Н. Научно-педагогическая мысль о морально-естетичес-ком воспитании средствами музыкального искусства.

В статье анализируются научные взгляды современных ученых на проблему взаимосвязи морального и эстетического в философских и психолого-педагогических исследованиях.

Ключевые слова: моральное, эстетическое, морально-эстетическое воспитание. 